\title{
Synthesis of Some Amidoalkyl naphthol and Benzoxanthene Derivatives by Zinc Oxide Nanoparticles Catalyst Under Solvent Free Condition and Evaluation of Their Antimicrobial and Antioxidant Activities
}

\author{
Demirew Abera ${ }^{1} \quad$ Hailemikael Tesso $^{2} \quad$ Abebe Belay $^{3}$ \\ 1.Ethiopian Institute of Agricultural Research (EIAR), Melkassa Agricultural Research Center (MARC), \\ P.O.Box 436, Melkassa, Ethiopia \\ 2.Department of Applied Chemistry, Adama Science and Technology University, P.O.Box 1888, Adama, \\ Ethiopia \\ 3.Department of Applied Physics, Adama Science and Technology University, P.O.Box 1888, Adama, Ethiopia
}

\begin{abstract}
Eco-friendly synthesis method was used to synthesize some amidoalkyl naphthol and benzoxanthene derivatives using zinc oxide nanoparticles under solvent free condition. The corresponding synthesized amidoalkyl naphthols A, B (89.8-90.4\%) and benzoxanthenes $\mathbf{C}$, D and $\mathbf{E}$ (89.4-93.5\%) were found higher yield than other reported methods. Antibacterial activity results of synthesized benzoxanthenes $\mathbf{D}$ and $\mathbf{E}$ showed activities with zone of inhibition $(\mathrm{mm})$ against all gram negative strains $(9-15 \mathrm{~mm})$ and gram positive bacterial strains $(9-13 \mathrm{~mm})$ tested where as benzoxanthene $\mathbf{C}$ was active against $B$. subtilis $(8,9,10 \mathrm{~mm}),(10,11,12 \mathrm{~mm})$ for both $B$. subtilis and E.coli. Amidoalkyl naphthol $\mathbf{A}$ showed activity against $B$. subtilis $(10,11,12 \mathrm{~mm})$ only and amidoalkyl naphthol B was active against both $B$. subtilis $(9,10,12 \mathrm{~mm})$ and E.coli $(10,11,15 \mathrm{~mm})$. Amongst all, the benzoxanthene $\mathbf{C}$ has only shown antifungal activity against $C$. albicuna $(12,14,16 \mathrm{~mm}$ zone of inhibition) even stronger than the standard fluconazole and amidoalkyl naphthol A, B and benzoxanthenes $\mathbf{D}, \mathbf{E}$ were inactive against $C$. albicuna. Except benzoxanthene $\mathbf{E}$, All the remaining synthesized compounds have shown promising antioxidant activities with $\mathrm{IC}_{50}$ values of $24.45,17.65,22.6$ and $47.56 \mu \mathrm{g} / \mathrm{ml}$ for amidoalkyl naphthol $\mathbf{A}$, $\mathbf{B}$, benzoxanthene $\mathbf{C}$ and $\mathbf{D}$ as compared to standard ascorbic acid $(9.28 \mu \mathrm{g} / \mathrm{ml})$ respectively.
\end{abstract}

Keywords: Antibacterial, Antifungal, Antioxidant, Amidoalkyl naphthols, Benzoxanthenes

DOI: $10.7176 / \mathrm{CMR} / 11-7-03$

Publication date:September $30^{\text {th }} 2019$

\section{Introduction}

Amidoalkyl naphthols and Benzoxanthenes are the class of organic compounds which are derived from naphthols and have vital roles in pharmaceutical applications. Synthesis of 1-amidoalkyl-2-naphthols is among one of the naphthol derivatives which have attracted strong interest due to their biological, medicinal and pharmacological activities [1]. It has been noted that 1-amidoalkyl-2-naphthols can be converted to hypotensive and bradycardia causing 1-aminomethyl-2- naphthol derivatives by amide hydrolysis reaction [2]. Besides to this, amidoalkyl naphthols can be converted to derivatives of 1,3-oxazines as an exclusive class of bioactive compounds that present in many biologically important natural products and drug candidates [3, 4], which exhibit broad ranges of biological activities such as antihypertensive [5],analgesic [6], antirheumatic [7], antianginal [8],antibacterial, and antiviral [9] and antimalarial [10]. Synthesis of xanthenes and their derivatives, especially benzoxanthenes have also attracted considerable interest due to their various pharmacological activities, such as antibacterial[11], antifungal [12], analgesic [13], anti-inflammatory [14], anti-viral [15,16], antioxidant [17], anti-cancer [18,19], cytotoxic [20], antiproliferative properties [21].

Numerous methods of synthesis of amidoalkyl naphthols and benzoxanthenes have been reported. The preparation of 1-amidoalkyl-2-naphthols can be carried out by multi-component condensation of aldehydes, 2naphthol and urea or amide in the presence of Lewis or Brønsted acid catalysts such as montmorillonite K10clay, silica-sodium hydrogen sulphate, Iodine, PentafluorophenylammoniumTriflate (PFPAT), phosphorus pentoxide $\left(\mathrm{P}_{2} \mathrm{O}_{5}\right)$, nanosilica phosphoric acid (H3PO4-SiO2),biodegradable ionic liquid [DDPA][HSO4],ultrasonic irradiation or use of microwave . On the other hand, different catalytic systems such as ionic liquid, hetero polyacid, sulfuric acid, sulfamic acid have been used to synthesize xanthenes and benzoxanthenes. However, the majority of them suffer from several limitations such as prolonged reaction time, side products, use of toxic solvents, highly acidic and expensive catalysts, and use of non-re-usable catalysts, unsatisfactory yield and high temperature. In view of these problems and due to ever-strengthening environmental regulations and safety concerns, it is essential to use a rapid, efficient and practical method for the synthesis of 1-amidoalkyl-2-naphthols and benzoxanthenes under eco-friendly conditions without those disadvantages stated above. The recent literature reveals that zinc oxide nanoparticles ( $\mathrm{nnO} N \mathrm{Ns}$ ) find application as heterogeneous catalysts and have received considerable attention because they are recyclable, high 
yield, reduce side products, short reaction time, inexpensive, nontoxic, easy to handle, nonvolatile and ecofriendly which can be used in many organic transformations. Synthesis of amidoalkyl naphthol and benzoxanthene derivatives are among one of the application of $\mathrm{ZnO}$ NPs. Therefore, in this project, 1amidoalkyl-2-naphthol derivatives and benzoxanthene derivatives were synthesized by using solvent free, zinc oxide nanoparticles ( $\mathrm{ZnO} \mathrm{NPs}$ ) catalyst and antimicrobial and antioxidant activities were evaluated for synthesized compounds and tested on selected human pathogens.

\section{Materials and Methods}

\subsection{Chemicals and Reagents}

The chemicals and reagents that were used in this investigation were Ethyl acetate (99\%), $n$-hexane( $99 \%)$, chloroform $\left(\mathrm{CDCl}_{3}\right)$, dimetylsulfoxide (DMSO), distilled water, tetramethylsilane(TMS), zinc oxide nanoparticles (ZnO NPs), methanol (99.8\%), ethanol (95\%), distilled water, silica gel, Urea, beta naphthol (99\%), benzaldehyde, vanillin (m-methoxy, p-hydroxybenzaldehyde), $P$-nitrobenzaldyde, $P$-methoxybenzaldehyde. All reagents and chemicals used in the synthesis were obtained from Sigma-Aldrich Co., St. Louis, MO, USA, and all solvents were purchased from Fine Chemical General Trading PLC, Addis Ababa, Ethiopia.

\subsection{Instrumentation}

Melting or decomposition point was determined by Stuart SMP3 digital melting point apparatus, expressed in ${ }^{\circ} \mathrm{C}$. IR spectra were recorded using Perkin-Elmer FT-IR spectrophotometer in the range of $4000-450 \mathrm{~cm}^{-1} .{ }^{1} \mathrm{H}$ and ${ }^{13} \mathrm{C}$ NMR was recorded using Bruker Avance $400 \mathrm{MHz}$ spectrometer using DMSO- $d_{6}$ as solvent and tetramethylsilane (TMS) as an internal standard and the values were expressed in $\delta$ ppm. The purity of the amidoalkyl naphthol and benzoxanthene derivatives were checked by thin layer chromatography (TLC) using silica Gel-G Pellets with layer thickness of $0.3 \mathrm{~mm}$. TLC visualization was realized by UV-light.

\subsection{Preparation of zinc oxide ( $\mathrm{ZnO}$ ) nanoparticles}

Zinc oxide $(\mathrm{ZnO})$ nanoparticles were prepared according to a literature method developed by Pacholski et al. [22] Zinc acetate dihydrated [ $\mathrm{Zn}(\mathrm{CH} 3 \mathrm{COO}) 2] .2 \mathrm{H} 2 \mathrm{O}, 2.4 \mathrm{~g})$ and $126 \mathrm{~mL}$ of water was added into a round bottom flask. The solution was heated to $60^{\circ} \mathrm{C}$ with magnetic stirring. The stock solution of potassium hydroxide $(\mathrm{KOH})$ was prepared by dissolving $1.2 \mathrm{~g}$ of $\mathrm{KOH}$ in to $70 \mathrm{~mL}$ of double distilled water. The stock solution was dropped into the flask within $10-15 \mathrm{~min}$. At a constant temperature of $60{ }^{\circ} \mathrm{C}$ for $2 \mathrm{hr}$. The solution was condensed to about $10-15 \mathrm{~mL}$ and reheated while stirring for another $5 \mathrm{hr}$ before stopping the heating. The upper fraction of the solution was removed after $30 \mathrm{~min}$ and water $(50 \mathrm{~mL})$ was added to the solution and stirred for $5 \mathrm{~min}$. The upper fraction of the solution was discarded again after $30 \mathrm{~min}$ and dried under vacuum to obtain zinc oxide $(\mathrm{ZnO})$ nanoparticles.

\subsection{Synthesis procedure for desired Compounds}

\subsubsection{Synthesis of amidoalkyl naphthols $(A, B)$ using ZnO NPs under Solvent free condition}

A mixture of benzaldehyde $(1 \mathrm{mmol}, 0.102 \mathrm{ml}), \beta$-naphthol $(1 \mathrm{mmol}, 0,144 \mathrm{~g})$, and urea $(1.2 \mathrm{mmol}, 0.072 \mathrm{~g})$ and catalytic amount of ZnO NPs $(20 \mathrm{~mol} \%, 0.2 \mathrm{mmol})$ were taken in $100 \mathrm{ml}$ conical flask and heated in an oil bath at $120^{\circ} \mathrm{C}$ for 42 minutes to synthesize compound $\mathbf{A}$ and 48 minutes to synthesize compound $\mathbf{B}$ with regular stirring. The progress of the reaction was monitored through TLC (ethyl acetate: n-hexane, 2:8) using precoated silica aluminium plates. The spots were visualized by ultraviolet light irradiation at $254 \mathrm{~nm}$. After completion, the reaction mixture was cooled to room temperature and ethyl acetate was added. The catalyst was separated from the reaction mixture by simple filtration. The filtrate was collected and dried. The obtained product (residue) was checked by TLC and purified using silica gel column chromatography (230-400 mesh, Merck), with increasing gradient of ethyl acetate in n-hexane as the mobile phase. Finally the product yield was recorded. By adopting the above synthetic procedure, compounds $\mathbf{A}$ and $\mathbf{B}$ were also synthesized.

\subsubsection{Synthesis of benzoxanthenes $(C, D$ and $E)$ using $\mathrm{ZnO}$ NPs under Solvent free condition.}

A mixture of benzaldehyde (1mmol, $0.102 \mathrm{ml})$, $\beta$-naphthol $(2 \mathrm{mmol}, 0.288 \mathrm{~g})$ and catalytic amount of ZnO NPs $(20 \mathrm{~mol} \%, 0.2 \mathrm{mmol})$ were taken in $100 \mathrm{ml}$ conical flask and heated in an oil bath at $120^{\circ} \mathrm{C}$ for 53 minutes,59 minutes and 55 minutes to synthesize compound $\mathbf{C}, \mathbf{D}$ and $\mathbf{E}$ with regular stirring respectively. The progress of the reaction was monitored through TLC (ethyl acetate: n-hexane, 2:8) using precoated silica aluminium plates. The spots were visualized by ultraviolet light irradiation at $254 \mathrm{~nm}$. After completion, the reaction mixture was cooled to room temperature and ethyl acetate was added. The catalyst was separated from the reaction mixture by simple filtration. The filtrate was collected and dried. The obtained product (residue) was checked by TLC and purified using silica gel column chromatography (230-400 mesh, Merck), with increasing gradient of ethyl acetate in $n$-hexane as the mobile phase. Finally the product yield was recorded. 


\subsection{Evaluation of Antimicrobial activity}

Antibacterial and antifungal activities of test samples were evaluated against the test strains according to using disc diffusion method [23]. Tetracycline was used as reference standard for antibacterial activity and fluconazole for fungal activity for comparing the results. All the compounds were tested at dose levels of $50 \mu \mathrm{g}(0.05 \mathrm{~mL})$, $100 \mu \mathrm{g}(0.1 \mathrm{ml}), 200 \mu \mathrm{g}(0.2 \mathrm{ml})$ and $10 \%$ DMSO solvent was used as a control. The solutions of each test compound, control and reference standard $(0.05 \mathrm{ml}, 0.1 \mathrm{ml}$ and $0.2 \mathrm{ml})$ were added separately in the cups and the plates were kept undisturbed for at least 2 hours in a refrigerator to allow diffusion of the solution properly into nutrient agar medium. Petri dishes were subsequently incubated at $37 \pm 1{ }^{\circ} \mathrm{C}$ for $24 \mathrm{hr}$ for bacteria and $48 \mathrm{hr}$ for fungi. After incubation, the diameter of zone of inhibition was measured.

\subsubsection{Antibacterial Activity}

The antibacterial activities of the synthesized compounds were tested against Escherichia coli ATCC 25922 and Pseudomonas Aeruginosa ATCC 7553 (Gram-negative bacteria), Bacillus subtilis ATCC 6633 and Staphylococcus aureus ATCC 25923 (Gram-positive bacteria) using Mueller Hinton agar (MHA) as a medium by disk diffusion method. The results have been compared with antibacterial agent tetracycline as standard drug. The results of the antibacterial activities of the synthesized compounds were determined by measuring the zone of inhibition in millimeter.

\subsubsection{Antifungal Activity}

All synthesized compounds were evaluated for their antifungal activities against Candidia Albicunas using TSA (tryptose soya agar) as medium by disk diffusion method. The results of this evaluation were compared with fluconazole as reference standard.

\subsection{Evaluation of Antioxidant Activity}

Antioxidant activity of the synthesized compounds was assessed according reported procedure [24] by the DPPH radical scavenging method (1, 1-Diphenyl-2-2picrylhydrazyl).The nitrogen centered stable free radical 1, 1diphenyl-2-picrylhydrazyl (DPPH) has often been used to characterize antioxidants. Ascorbic acid was used as the standard. The activity was expressed as $\mathrm{IC}_{50}$, which is the concentration of the test compound required to give a $50 \%$ decrease of the absorbance from that of the control solution. The inhibition curves were prepared and IC50 values were obtained. The percent of inhibition (I \%) of free radical production from DPPH was calculated by the following equation:

$\%$ of $\mathrm{I}=\left[\left(\mathrm{A}_{\text {control }}-\mathrm{A}_{\text {sample }}\right) / \mathrm{A}_{\text {control }}\right] \times 100$

Where $\mathrm{A}_{\text {control }}$ is the absorbance of the control reaction, $A_{\text {sample }}$ is the absorbance of the test compound.

\section{Results and Discussion}

\subsection{Comparison of $20 \%$ of ZnO NPs (present work) with reported catalysts in the synthesis of amidoalkyl naphthols and benzoxanthenes}

In order to show the merit of the present work in comparison with reported results in the literature, we compared the reactions of $\mathrm{ZnO}$ NPs with Montmorillonite $\mathrm{K} 10$ clay [25], $\mathrm{K}_{5} \mathrm{CoW}_{12} \mathrm{O}_{40} .3 \mathrm{H}_{2} \mathrm{O}$ [26] and $\mathrm{Ce}\left(\mathrm{SO}_{4}\right)_{2}$ [27] in the synthesis of 1-amidomethyl-2-naphthol derivatives (Table 2). Zinc oxide nanoparticles (ZnO NPs) was an efficient catalyst in the formation of compound $\mathbf{A}$ and $\mathbf{B}$ with high yields and shorter reaction times (Table 1). The results obtained in this work for the synthesis of benzoxanthenes $\mathbf{C}, \mathbf{D}$ and $\mathbf{E}$ were compared with other studies detailed in the literature with Camphor-10-sulfonic acid((t)-CSA) [28], p-TSA [29] and Vanadate Sulfuric Acid NRs $\left(\mathrm{O}_{2} \mathrm{~V}-\mathrm{OSO}_{3} \mathrm{H}\right)$ [30] (Table 4). Zinc oxide nanoparticles ( $\mathrm{ZnO}$ NPs) proved to be the only one capable of promoting this one-pot reaction with high yield and shorter reaction time (Table 3 ). As reported in the literature 31-33, a mechanism for the synthesis of 1-amidoalkyl-2-naphthols is shown in scheme 1. In general the nano particle is considered to be more reactive because it offers higher surface area and low coordinating sites. High catalytic activity is obtained by increasing surface area of the catalyst by decreasing of the particle size to nano levels which ultimately leads to drastic increase in reaction rate. To the best of our knowledge, $\mathrm{ZnO}$ NPs has been proposed to activate the aldehyde by coordinating to oxygen atom which ultimately enhances the electrophilicity of the aldehyde and leads to reduction in reaction time.The condention of 2-naphthol with the activated aldehyde give ortho-quinone-methides(o-QMs) as a highly reactive and ephemeral intermediate. The same o-QMs, generated in situ have been reacted with amide under the influence of $\mathrm{ZnO}$ NPs to form 1amidoalkyl-2-naphthol derivatives. Thus, the 2-naphthol act as Michael acceptors and aldehyde araldehydes as nucleophile resulting in a Mechael adduct under the influence of $\mathrm{ZnO}$ NPs. The electron withdrawing groups (EWD) substituted on benzaldehyde in o-QM intermediate increase the rate of 1, 4-nucleophilic addition reaction because the alkene LUMO is at lower energy in the neighbouring electron withdrawing groups (EWD) than electron donating groups(EDG). Hence the benzene ring with electron with drawing groups gave better as compared to electron donating groups. On the other hand, suggested reaction mechanism pathway of the synthesis of dibenzoxanthenes using $\mathrm{ZnO}$ NPs presented in Scheme 2. Activation of the carbonyl group of aldehyde by $\mathrm{ZnO} \mathrm{NPs}$, facilitates nucleophilic attack of 2-naphthol and formation of the corresponding 
carbocation in the first step. This carbocation was then transformed to an aryl methanebisnaphthol in the second step, and ultimately it was converted to the desired product via dehydration of bis (naphtholyl) methane species.

Table 2: Physical characterization data of synthesized amidoalkyl naphthols

\begin{tabular}{cccccc}
\hline Compound & R & Color & Time (min) & Melting point & Yield obtained \\
\hline A & $\mathrm{H}$ & White solid & 42 & $177-179$ & 90.4 \\
B & $\mathrm{OCH}_{3}$ & White solid & 48 & $169-171$ & 89.8 \\
\hline
\end{tabular}

Table 3: Comparison of $20 \%$ of ZnO NPs with reported catalysts in the synthesis ofamidoalkyl naphthols (1amidoalkyl-2-naphthols)

\begin{tabular}{llcll}
\hline Catalyst & $\mathbf{M o l} \% /[\mathbf{g}] /$ conditions $/ \mathbf{T} /{ }^{\mathbf{C}} \mathbf{C}$ & Time/min & Yield/\% & Reference \\
\hline Montmorillonite K10 clay & $(0.1 \mathrm{~g}) ;$ Solvent free, $125^{\circ} \mathrm{C}$ & 90 & 78 & 25 \\
$\mathrm{~K}_{\mathbf{5}} \mathrm{CoW}_{\mathbf{1 2}} \mathrm{O}_{\mathbf{4 0 . 3}} \mathbf{3 H}_{\mathbf{2}} \mathrm{O}$ & $(1 \mathrm{~mol} \%) ;$ Solvent free, $125^{\circ} \mathrm{C}$ & 120 & 80 & 26 \\
$\mathbf{C e}\left(\mathrm{SO}_{4}\right)_{2}$ & $(1 \mathrm{mmol}), \mathrm{CH}_{3} \mathrm{CN}, \mathrm{Reflux}$ & 2160 & 72 & 27 \\
\hline
\end{tabular}

Table 4: Physical characterization data of synthesized benzoxanthenes

$\begin{array}{llllll}\text { Compound } & R & \text { Color } & \text { Time }(\text { min) } & \text { Melting point }\left({ }^{\circ} \mathrm{C}\right) & \text { Yield obtained }\end{array}$

$\begin{array}{lccccc}\text { C } & \mathrm{H} & \text { White solid } & 53 & 183-185 & 89.4 \\ \mathbf{D} & \mathrm{OCH}_{3} & \text { Yellow solid } & 59 & 204-205 & 92.0 \\ \text { E } & \mathrm{NO}_{2} & \text { Yellow solid } & 55 & 314-315 & 93.5\end{array}$

Table 5: Comparison of $20 \%$ of ZnO NPs with reported catalysts in the synthesis of benzoxanthenes (14-aryl14H-dibenzo [a,j] xanthenes)

\begin{tabular}{|c|c|c|c|c|}
\hline Catalyst & Mol\%/[g]/conditions/T/ ${ }^{\circ} \mathrm{C}$ & Time/min & Yield/\% & Reference \\
\hline Camphor-10-sulfonic acid(( \pm )-CSA $)$ & $\begin{array}{l}(20 \mathrm{mo} \%) ; \text { Solvent free, } 25^{\circ} \\
\mathrm{C}\end{array}$ & 930 & 21 & 28 \\
\hline p-TSA & $(0.1 \mathrm{~g}) ; \mathrm{H}_{2} \mathrm{O}$, reflux & 600 & 88 & 29 \\
\hline $\begin{array}{l}\text { Vanadate Sulfuric Acid NRs( } \mathrm{O}_{2} \mathrm{~V}- \\
\left.\mathrm{OSO}_{3} \mathrm{H}\right)\end{array}$ & Chloroform, $80^{\circ} \mathrm{C}$ & 600 & 60 & 30 \\
\hline
\end{tabular}

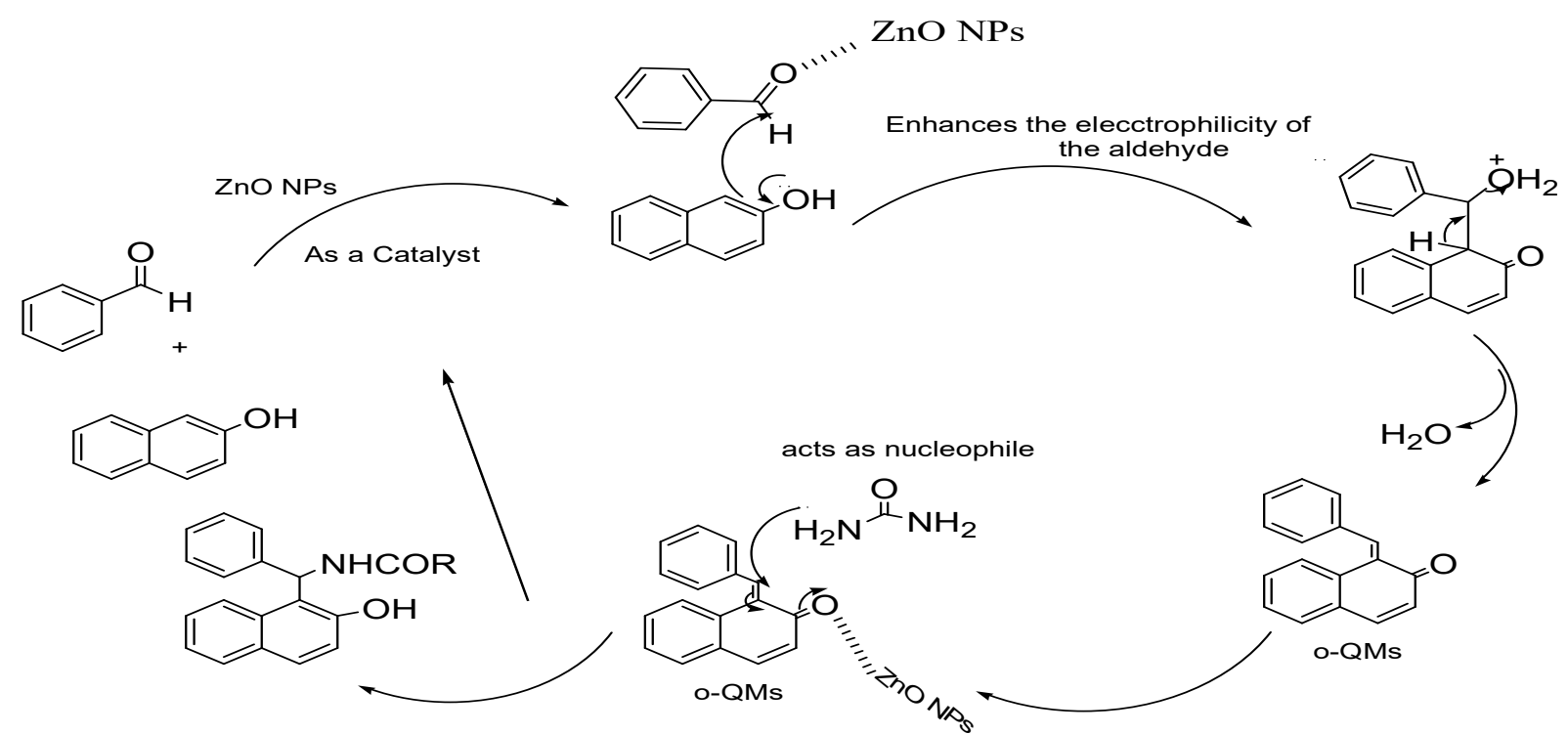

Scheme 1: Plausible mechanism of ZnO NPs promoted synthesis of amidoalkylnaphthols 

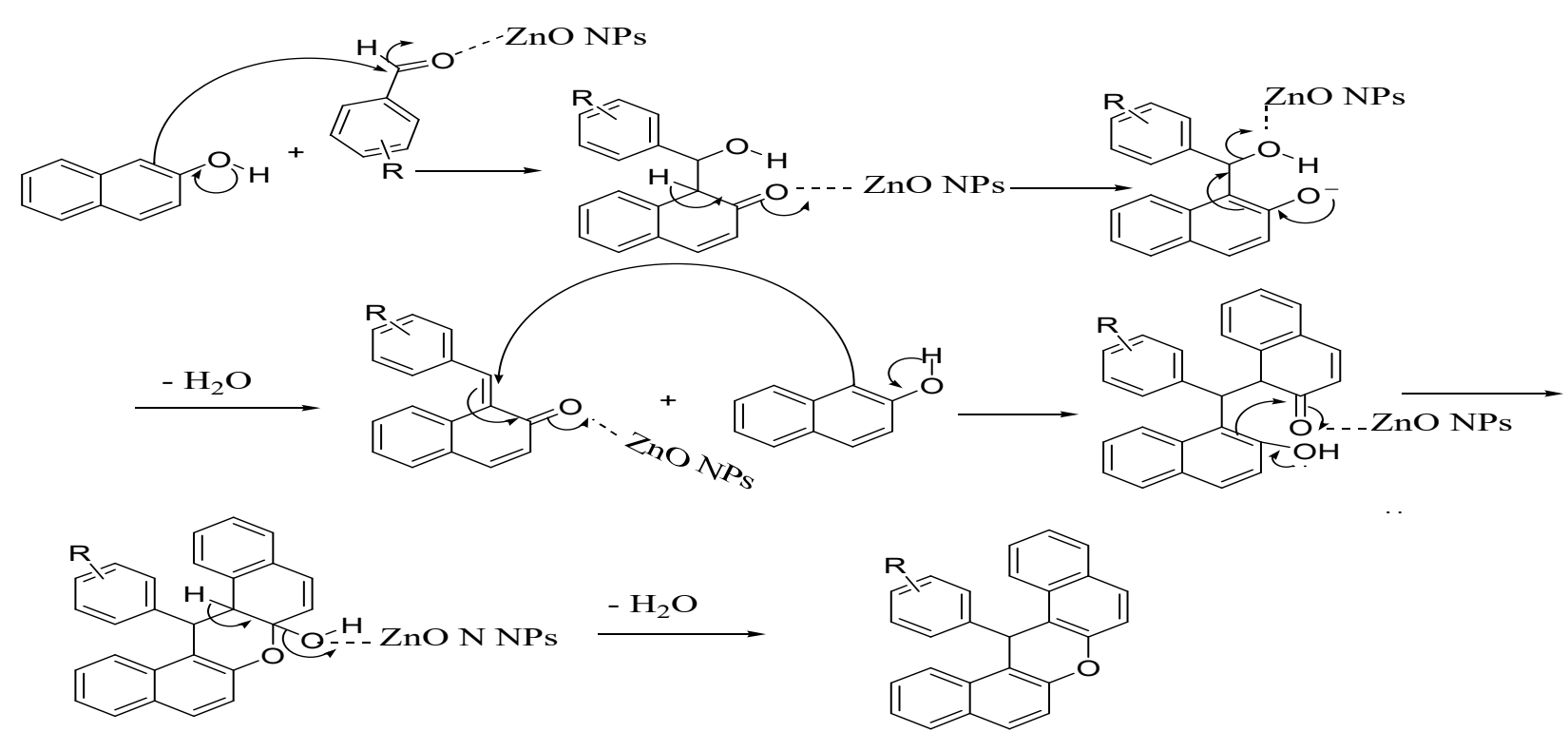

Scheme 2: Plausible mechanism action of $\mathrm{ZnO}$ NPs promoted synthesis of benzoxanthenes

\subsection{Characterization of Synthesized compounds}

\subsubsection{Characterization of compound $A$}

Compound A was obtained as white solid with melting point of $177-179^{\circ} \mathrm{C}$ and its percent yield was $90.4 \%$. The IR ( $\mathrm{KBr}$ pellet) spectrum showed $\left(\mathrm{v}\right.$ in $\left.\mathrm{cm}^{-1}\right)$ broad absorption at $3462 \mathrm{~cm}^{-1}$ attributed to $\mathrm{O}-\mathrm{H}$ stretching and 3223 $\mathrm{cm}^{-1}$ to N-H stretching. The intense absorption bands at $1666 \mathrm{~cm}^{-1}$ and at $1437 \mathrm{~cm}^{-1}$ showed the presence of carbonyl carbon and aromatic C-C double bond respectively. The ${ }^{1} \mathrm{H}$ NMR spectrum (DMSO-d6, $400 \mathrm{MHz}$ ) showed a single peak at $\delta 5.85(1 \mathrm{H}, \mathrm{s})$ corresponding to a hydroxyl group on the aromatic ring and a single peak at $\delta 6.95(1 \mathrm{H}, \mathrm{s})$ showed the presence of methine proton at $\mathrm{C}-2$. The peaks from $\delta 7.21-7.12(2 \mathrm{H}, \mathrm{m})$ showed the presence of aromatic protons at C-16, C-14, C-14' respectively. The peaks at $\delta 7.24(1 \mathrm{H}, \mathrm{d}, \mathrm{J}=7.2)$ at $\mathrm{C}-5$, from $\delta$ 7.34-7.26 $(2 \mathrm{H}, \mathrm{m})$ at $\mathrm{C}-15, \mathrm{C}-15$ ', from $\delta 7.39-7.38(1 \mathrm{H}, \mathrm{m})$ at $\mathrm{C}-11$, from $\delta 7.45-7.41(1 \mathrm{H}, \mathrm{m})$ at $\mathrm{C}-10, \delta 7.49$ $(1 \mathrm{H}, \mathrm{d}, \mathrm{J}=8.8 \mathrm{~Hz})$ at $\mathrm{C}-6$, at $\delta 7.77(1 \mathrm{H}, \mathrm{d}, \mathrm{J}=7.2 \mathrm{~Hz})$ at $\mathrm{C}-12$ and at $\delta 7.83(1 \mathrm{H}, \mathrm{d}, \mathrm{J}=8 \mathrm{HZ})$ at $\mathrm{C}-9$ showed the presence of aromatic protons. The peak at $\delta 8.32$ as singlet indicated the presence of $1 \mathrm{H}$ for $\mathrm{NH}$ and $2 \mathrm{H}$ for $\mathrm{NH}_{2}$. The ${ }^{13} \mathrm{C}$ NMR spectrum revealed peak resonating at $\delta 159.0$ at $\mathrm{C}-1$ attributed to carbonyl carbon. The peaks observed at $\delta 129.4$ at C-15 and C-15', and at $\delta 129.0$ at C-14 and C-14' showed that the presence of sp ${ }^{2}$ carbon on the benzene ring whereas the peak observed at $\delta 153.4$ indicated the presence of oxygenated quaternary carbon at C-4. On the other hand the peaks at $\delta 132.7$ at C-8 and $\delta 128.3$ at C-7, and at $\delta 48.6$ at C-2 showed that the presence of non-oxygenated quaternary carbon and methine carbon respectively. Thus, on the basis of ${ }^{1} \mathrm{H}-$ NMR, ${ }^{13} \mathrm{C}$ NMR and IR spectra data, the structure of compound A was established as Amidoalkyl naphthol: [(2Hydroxy-naphthalen-1-yl)-phenyl-methyl]-urea.

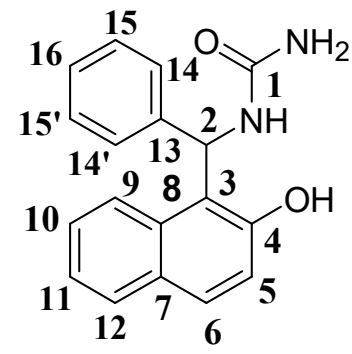

A

\subsubsection{Characterization of compound $B$}

Compound B was obtained as white solid with melting $169-171^{\circ} \mathrm{C}$ and its percent yield was $89.8 \%$. From IR ( $\mathrm{KBr}$ pellet) spectrum showed $\left(\mathrm{v}\right.$ in cm $\mathrm{cm}^{-1}$ ) broad absorption band at $3430 \mathrm{~cm}^{-1}$ and at $3267 \mathrm{~cm}^{-1}$ attributed to $\mathrm{O}-\mathrm{H}$ and $\mathrm{N}-\mathrm{H}$ stretching respectively. The intense absorption bands at $1736 \mathrm{~cm}^{-1}$ and at $1178 \mathrm{~cm}^{-1}$ showed the presence of carbonyl carbon and O-C stretching for methoxy group respectively. The ${ }^{1} \mathrm{H}$ NMR spectrum showed a single peak at $\delta 6.06(1 \mathrm{H}, \mathrm{s})$ corresponding to a hydroxy group on the aromatic ring and a single peak at $\delta 6.49$ $(1 \mathrm{H}, \mathrm{s})$ showed the presence of methine proton at C-2. A single peak at $\delta 3.76(3 \mathrm{H}, \mathrm{s})$ at $\mathrm{C}-16$ and at $\delta 6.07(1 \mathrm{H}$,$\mathrm{NH})$ and $\left(2 \mathrm{H},-\mathrm{CONH}_{2}\right)$ showed the presence of methoxy group on the benzene ring and, amine and amide protons respectively. The peaks at $\delta 6.85(1 \mathrm{H}, \mathrm{d}, \mathrm{J}=8.4 \mathrm{~Hz})$ at $\mathrm{C}-15$ and $\mathrm{C}-15$, at $\delta 7.22(1 \mathrm{H}, \mathrm{d}, \mathrm{J}=8.8 \mathrm{~Hz})$ at $\mathrm{C}$ - 
14 and C-14' showed the presence of aromatic protons. The peaks at $\delta 7.36(1 \mathrm{H}, \mathrm{d} \mathrm{J}=9.2)$ at $\mathrm{C}-5, \delta 7.89(1 \mathrm{H}, \mathrm{d}$, $\mathrm{J}=8.8 \mathrm{~Hz})$ at $\mathrm{C}-9$, from $\delta 7.89-7.41(4 \mathrm{H}, \mathrm{m})$ indicated the aromatic protons on ring. From ${ }^{13} \mathrm{C}$ NMR spectrum, the peaks at $\delta 159.7$ at $\mathrm{C}-1$ and $\delta 55.6$ at $\mathrm{C}-2$ showed that the presence of carbonyl carbon and methoxy group respectively (Appendix 2C). The peaks observed at $\delta 114.7$ is due to C-15 and C-15', and at $\delta 130.5$ at C-14 and $\mathrm{C}-14$ ' showed that the presence of $\mathrm{sp}^{2}$ carbon on the benzene ring A whereas the peak observed at $\delta 150.3$ and $\delta$ 147.5 indicated the presence of oxygenated quaternary carbon at C-17 and C-4 respectively. Besides to this the peaks at $\delta 131.0$ at $\mathrm{C}-8$ and $\delta 129.4$ at $\mathrm{C}-7$ showed that the presence of non-oxygenated quaternary carbon. Thus, on the basis of ${ }^{1} \mathrm{H}-\mathrm{NMR},{ }^{13} \mathrm{C}-\mathrm{NMR}$ and IR spectra data, the structure of compound $\mathbf{B}$ was established as amidoalkyl naphthol: [(2-hydroxy-naphthalen-1-yl)-(4-methoxy-phenyl)-methyl]-urea.

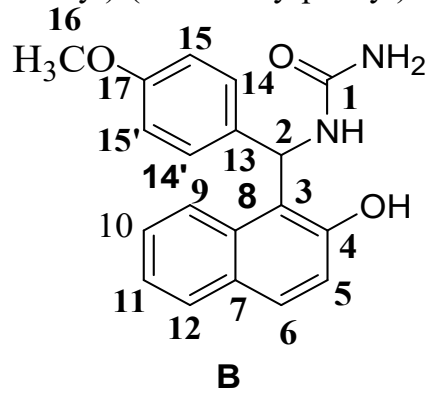

\subsubsection{Characterization of compound $\mathrm{C}$}

Compound $\mathbf{C}$ was obtained as white solid with melting point of $184-186^{\circ} \mathrm{C}$ and its percent yield was $89.4 \%$. From IR ( $\mathrm{KBr}$ pellet) spectrum ( $\mathrm{v}$ in cm $\mathrm{cm}^{-1}$ ), absorption band at $1593 \mathrm{~cm}^{-1}$ and at $1431 \mathrm{~cm}^{-1}$ indicated the presence of aromatic $\mathrm{C}-\mathrm{C}$ double bond . The intense absorption bands at $1254 \mathrm{~cm}^{-1}$ showed $-\mathrm{C}-\mathrm{O}-\mathrm{C}$ stretching. The ${ }^{1} \mathrm{H}$ NMR spectrum of $\mathbf{C}$ exhibited a doublet for the aromatic protons at $\delta 8.44(1 \mathrm{H}, \mathrm{d}, \mathrm{J}=8.4 \mathrm{~Hz})$ at $\mathrm{C}-12$ and $\mathrm{C}-12$ ', at $\delta 7.86(1 \mathrm{H}, \mathrm{d}, \mathrm{J}=8.0 \mathrm{~Hz})$ at $\mathrm{C}-9$ and $\mathrm{C}-9$ ', at $\delta 7.83(1 \mathrm{H}, \mathrm{d}, \mathrm{J}=8.8 \mathrm{~Hz})$ at $\mathrm{C}-2$ and $\mathrm{C}-2^{\prime}$, at $\delta 7.53$ $(1 \mathrm{H}, \mathrm{d}, \mathrm{J}=8.8 \mathrm{~Hz})$ at $\mathrm{C}-3$ and $\mathrm{C}-3$ ', and a multiplet for the 4 aromatic protons at $\delta 7.46-7.16 \mathrm{ppm}$ and 4 aromatic protons at $\delta 7.63-7.55 \mathrm{ppm}$. The peak at $\delta 6.52(1 \mathrm{H}, \mathrm{C}-\mathrm{H}, \mathrm{s})$ at $\mathrm{C}-8$ showed a single peak for the presence of methine proton. From ${ }^{13} \mathrm{C}$ NMR spectrum, the peak observed at $\delta 148.8$ at C-4 and C-4', and $\delta 145.0$ at C-13 showed the presence of oxygenated quaternary carbon and non-oxygenated quaternary carbon on the benzene ring respectively. The peaks observed at $\delta 131.5$ at C-6 and C-6', and at $\delta 131.1$ at $\mathrm{C}-1$ and $\mathrm{C}-1$ ' showed that the presence of non-oxygenated carbon whereas the peak observed at $\delta 128.8$ for C-14, C-14', C-15, C-15', and $\delta$ 128.4 for C-9 and C-9', $\delta 128.3$ for C-2 and C-2' indicated the presence of $\mathrm{sp}^{2}$ of aromatic carbon. The peak at $\delta$ 38.1 at $\mathrm{C}-8$ indicated the presence of methine carbon. Thus, on the basis of ${ }^{1} \mathrm{H}$ NMR, ${ }^{13} \mathrm{C}$ NMR and IR spectra data, the structure of compound $\mathbf{C}$ was established as benzoxanthene: 14-Phenyl-14H-Dibenzo [a, j] xanthene.

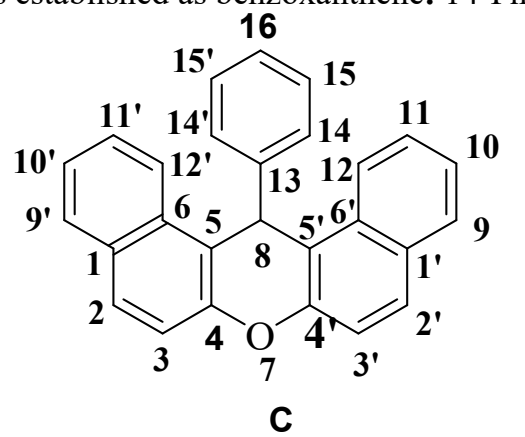

\subsubsection{Characterization of compound $D$}

Compound $\mathbf{D}$ was obtained as yellowish solid with melting point of $203-205^{\circ} \mathrm{C}$ and its percent yield was $92 \%$. From IR ( $\mathrm{KBr}$ pellet) spectrum ( $\mathrm{v}$ in cm $\mathrm{cm}^{-1}$ ), absorption band at $1602 \mathrm{~cm}^{-1}$ and at $1514 \mathrm{~cm}^{-1}$ showed the presence of aromatic c-c double bond stretching. The intense absorption bands at $1218 \mathrm{~cm}^{-1}$ and 1163 indicated $-\mathrm{C}-\mathrm{O}-\mathrm{C}$ and $-\mathrm{O}-\mathrm{CH}_{3}$ stretching respectively. The ${ }^{1} \mathrm{H}$ NMR spectrum of $\mathbf{D}$ exhibited a doublet for the aromatic protons at $\delta 7.71(1 \mathrm{H}, \mathrm{d}, \mathrm{J}=8)$ at $\mathrm{C}-2$ and $\mathrm{C}-2{ }^{\prime}$, at $\delta 7.05(1 \mathrm{H}, \mathrm{d}, \mathrm{J}=8.8 \mathrm{~Hz})$ at $\mathrm{C}-3$ and $\mathrm{C}-3$ ', and a multiplet for the 4 aromatic protons at $\delta 7.48-7.34 \mathrm{ppm}$ and 4 aromatic protons at $\delta 7.91-7.77 \mathrm{ppm}$. The peak at $\delta 5.56(1 \mathrm{H}, \mathrm{C}-\mathrm{H}, \mathrm{s})$ at $\mathrm{C}-8$ and at $\delta 3.92$ at $\mathrm{C}-17$ showed a single peak for the presence of methine proton and methoxy group respectively. From ${ }^{13} \mathrm{C}$ NMR spectrum, the peak observed at $\delta 164.9$ at C-16, $\delta 153.5$ at C-4 and C-4', and at $\delta$ 134.6 at $\mathrm{C}-13$ showed the presence of oxygenated quaternary carbon and non-oxygenated quaternary carbon on the benzene ring respectively. The peaks observed at $\delta 132.3$ at C-6 and C-6', and at $\delta 128.5$ at C-1 and C-1' showed that the presence of non-oxygenated carbon whereas the peak observed at $\delta 129.9$ for C-14 and C-14', and $\delta 109.5$ for C-15 and C-15', $\delta 127.8$ for C-2 and C-2' indicated the presence of $\mathrm{sp}^{2}$ of aromatic carbon. Thus, 
on the basis of ${ }^{1} \mathrm{H}$ NMR, ${ }^{13} \mathrm{C}$ NMR and IR spectra data, the structure of compound $\mathbf{3 0}$ was established as benzoxanthene:14-(4-Methoxy -Phenyl) -14H-dibenzo [a,j] xanthene.

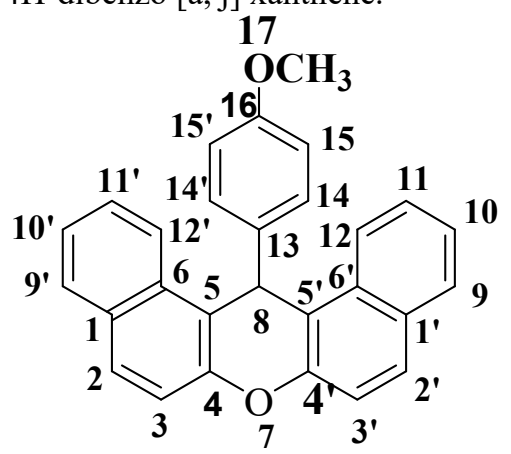

D

\subsubsection{Characterization of compound $E$}

Compound $\mathbf{E}$ was obtained as yellow solid with melting point of $314-215^{\circ} \mathrm{C}$ and its percent yield was $93.5 \%$. From IR ( KBr pellet) spectrum $\left(\mathrm{v}\right.$ in cm $\mathrm{cm}^{-1}$ ), the intense peak observed at $1592 \mathrm{~cm}^{-1}$ and at $1415 \mathrm{~cm}^{-1}$ showed the presence of aromatic c-c double bond stretching whereas the intense absorption bands at $1341 \mathrm{~cm}^{-1}$ and 1240 $\mathrm{cm}^{-1}$ indicated $-\mathrm{C}-\mathrm{O}-\mathrm{C}$ stretching and $\mathrm{NO}_{2}$ attached to aromatic system respectively. The ${ }^{1} \mathrm{H}$ NMR spectrum of E exhibited a doublet for the aromatic protons at $\delta 8.04(1 \mathrm{H}, \mathrm{d}, \mathrm{J}=8.8 \mathrm{~Hz})$ for C-12, C-12' , C-9 and C-9', at $\delta$ $8.32(1 \mathrm{H}, \mathrm{d}, \mathrm{J}=9.6)$ for $\mathrm{C}-15$ and $\mathrm{C}-15^{\prime}$, and at $\delta 7.72(1 \mathrm{H}, \mathrm{d}, \mathrm{J}=8.8 \mathrm{~Hz})$ for $\mathrm{C}-14$ and $\mathrm{C}-14^{\prime}, \delta$ $7.87(1 \mathrm{H}, \mathrm{d}, \mathrm{J}=8.8 \mathrm{~Hz})$ for $\mathrm{C}-2$ and $\mathrm{C}-2^{\prime}$, at $\delta 7.54(1 \mathrm{H}, \mathrm{d}, \mathrm{J}=8.8 \mathrm{~Hz})$ for $\mathrm{C}-3$ and $\mathrm{C}-3$ '. The peak at $\delta 7.49-7.45(1 \mathrm{H}$, $\mathrm{m})$ for $\mathrm{C}-10$ and $\mathrm{C}-10$ ', and $87.65-7.60(1 \mathrm{H}, \mathrm{m})$ for C-11 and C-11') showed multiple spectra for the 4 aromatic protons respectively. The peak at $\delta 6.63(1 \mathrm{H}, \mathrm{C}-\mathrm{H}, \mathrm{s})$ at $\mathrm{C}-8$ showed a single peak for the presence of methine proton of $\mathrm{sp}^{3}$ carbon. From ${ }^{13} \mathrm{C}$ NMR spectrum, the peak observed at $\delta 152.0$ at C-4 and C-4', at $\delta 148.8$ at C13 and $\delta 146.3$ at $\mathrm{C}-16$ showed the presence of oxygenated quaternary carbon, non-oxygenated quaternary carbon and quaternary carbon attached with $\mathrm{NO}_{2}$ on the benzene ring respectively. The peaks observed at $\delta$ 131.1 at C-6 and C-6', and at $\delta 129.1$ at C-1 and C-1' showed that the presence of non-oxygenated carbon whereas the peak observed at $\delta 129.6$ for $\mathrm{C}-14$ and C-14', and $\delta 124.6$ for $\mathrm{C}-15$ and $\mathrm{C}-15^{\prime}, \delta 128.9$ for $\mathrm{C}-2$ and C-2' indicated the presence of $\mathrm{sp}^{2}$ of aromatic carbon. The peak at $\delta 37.9$ at C-8 indicated the presence of methine carbon. Thus, on the basis of ${ }^{1} \mathrm{H}$ NMR, ${ }^{13} \mathrm{C}$ NMR and IR spectra data, the structure of compound $\mathbf{E}$ was established as benzoxanthene: 14-( 4-Nitro-Phenyl ) - 14H - dibenzo [a,j] xanthene.

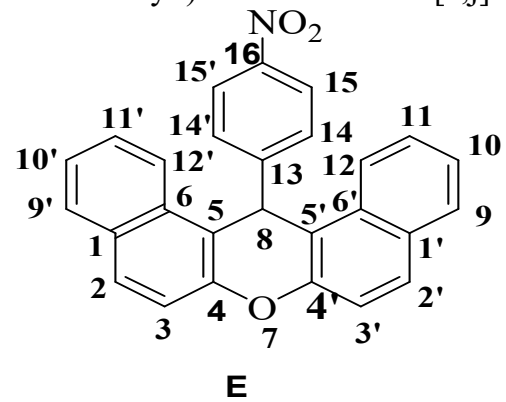

\subsection{Antimicrobial Activity}

3.3.1. Antibacterial Activity

The results of the antibacterial activities of the synthesized compounds were determined by measuring the zone of inhibition in millimeter. The compound A was active against Bacillus Subtilis (Gram-positive bacteria) at all concentrations tested and inactive against Strophylococcus Aureus (Gram-positive bacteria) Escherichia Coli and Pseudomonas Aeruginosa (Gram-negative bacteria). The compound B did not show any activity against Grampositive bacteria (Strophylococcus Aureus) and Gram -negative bacteria (Pseudomonas Aeruginosa) at all three concentrations $(50,100$ and $200 \mu \mathrm{g} / \mathrm{ml})$ and showed activity against Gram-positive bacteria (Bacillus Subtilis) and Gram-negative bacteria (Escherichia Coli) at all three concentrations tested where as compound C showed activity against Gram-positive bacteria (Bacillus Subtilis),Escherichia Coli and Pseudomonas Aeruginosa (Gram-negative bacteria) and did not show any activity against Strophylococcus Aureus(Gram-positive bacteria). The compound $\mathbf{D}$ and $\mathbf{E}$ were active and showed activity, at all concentrations tested, against both Gram-positive and Gram-negative organisms (Table 5). 
Table 6: Antibacterial activities of the synthesized compounds

\begin{tabular}{|c|c|c|c|c|c|c|c|c|c|c|c|c|}
\hline \multirow{5}{*}{$\begin{array}{l}\stackrel{\Xi}{\Xi} \\
\bar{\Xi} \\
\ddot{\Xi} \\
\dot{\Xi}\end{array}$} & \multicolumn{12}{|c|}{ Zone of inhibition(mm) } \\
\hline & \multicolumn{6}{|c|}{ Gram positive Bacteria } & \multicolumn{6}{|c|}{ Gram negative Bacteria } \\
\hline & \multicolumn{3}{|c|}{$\begin{array}{l}\text { StrophylococcusAureu } \\
s\end{array}$} & \multicolumn{3}{|c|}{ Bacillus Subtilis } & \multicolumn{3}{|c|}{ Escherichia Coli } & \multicolumn{3}{|c|}{$\begin{array}{l}\text { Pseudomonas } \\
\text { Aeruginosa }\end{array}$} \\
\hline & \multicolumn{3}{|c|}{ Concentration $(\mu \mathrm{g} / \mathrm{ml})$} & \multicolumn{3}{|c|}{ Concentration $(\mu \mathrm{g} / \mathrm{ml})$} & \multicolumn{3}{|c|}{ Concentration $(\mu \mathrm{g} / \mathrm{ml})$} & \multicolumn{3}{|c|}{ Concentration $(\mu \mathrm{g} / \mathrm{ml})$} \\
\hline & 50 & 100 & 200 & 50 & 100 & 200 & 50 & 100 & 200 & 50 & 100 & 200 \\
\hline $\mathbf{A}$ & $6 \mathrm{~mm}$ & $6 \mathrm{~mm}$ & $6 \mathrm{~mm}$ & $\begin{array}{c}10 \mathrm{~m} \\
\mathrm{~m}\end{array}$ & $\underset{\mathrm{m}}{11 \mathrm{~m}}$ & $\begin{array}{c}12 \mathrm{~m} \\
\mathrm{~m}\end{array}$ & $6 \mathrm{~mm}$ & $6 \mathrm{~mm}$ & $6 \mathrm{~mm}$ & $6 \mathrm{~mm}$ & $6 \mathrm{~mm}$ & $6 \mathrm{~mm}$ \\
\hline B & $6 \mathrm{~mm}$ & $6 \mathrm{~mm}$ & $6 \mathrm{~mm}$ & $9 \mathrm{~mm}$ & $\begin{array}{c}10 \mathrm{~m} \\
\mathrm{~m}\end{array}$ & $\begin{array}{c}12 \mathrm{~m} \\
\mathrm{~m}\end{array}$ & $\begin{array}{c}10 \mathrm{~m} \\
\mathrm{~m}\end{array}$ & $\underset{\mathrm{m}}{11 \mathrm{~m}}$ & $\begin{array}{c}15 \mathrm{~m} \\
\mathrm{~m}\end{array}$ & $6 \mathrm{~mm}$ & $6 \mathrm{~mm}$ & $6 \mathrm{~mm}$ \\
\hline $\mathbf{C}$ & $6 \mathrm{~mm}$ & $6 \mathrm{~mm}$ & $6 \mathrm{~mm}$ & $8 \mathrm{~mm}$ & $9 \mathrm{~mm}$ & $\begin{array}{c}10 \mathrm{~m} \\
\mathrm{~m}\end{array}$ & $\begin{array}{c}10 \mathrm{~m} \\
\mathrm{~m}\end{array}$ & $\underset{\mathrm{m}}{11 \mathrm{~m}}$ & $\begin{array}{c}12 \mathrm{~m} \\
\mathrm{~m}\end{array}$ & $\begin{array}{c}10 \mathrm{~m} \\
\mathrm{~m}\end{array}$ & $\underset{\mathrm{m}}{11 \mathrm{~m}}$ & $\begin{array}{c}12 \mathrm{~m} \\
\mathrm{~m}\end{array}$ \\
\hline D & $9 \mathrm{~mm}$ & $\begin{array}{c}10 \mathrm{~m} \\
\mathrm{~m}\end{array}$ & $\begin{array}{c}13 \mathrm{~m} \\
\mathrm{~m}\end{array}$ & $8 \mathrm{~mm}$ & $9 \mathrm{~mm}$ & $\begin{array}{c}10 \mathrm{~m} \\
\mathrm{~m}\end{array}$ & $9 \mathrm{~mm}$ & $\begin{array}{c}10 \mathrm{~m} \\
\mathrm{~m}\end{array}$ & $\begin{array}{c}15 \mathrm{~m} \\
\mathrm{~m}\end{array}$ & $8 \mathrm{~mm}$ & $9 \mathrm{~mm}$ & $\begin{array}{c}10 \mathrm{~m} \\
\mathrm{~m}\end{array}$ \\
\hline $\mathbf{E}$ & $\begin{array}{l}10 \mathrm{~m} \\
\mathrm{~m}\end{array}$ & $\underset{\mathrm{m}}{11 \mathrm{~m}}$ & $\begin{array}{c}12 \mathrm{~m} \\
\mathrm{~m}\end{array}$ & $9 \mathrm{~mm}$ & $\begin{array}{c}10 \mathrm{~m} \\
\mathrm{~m}\end{array}$ & $\begin{array}{c}12 \mathrm{~m} \\
\mathrm{~m}\end{array}$ & $9 \mathrm{~mm}$ & $\begin{array}{c}10 \mathrm{~m} \\
\mathrm{~m}\end{array}$ & $\begin{array}{c}12 \mathrm{~m} \\
\mathrm{~m}\end{array}$ & $\begin{array}{c}10 \mathrm{~m} \\
\mathrm{~m}\end{array}$ & $\underset{\mathrm{m}}{11 \mathrm{~m}}$ & $\begin{array}{c}12 \mathrm{~m} \\
\mathrm{~m}\end{array}$ \\
\hline $\begin{array}{c}\text { Tetracycli } \\
\text { ne }\end{array}$ & $\begin{array}{l}10 \mathrm{~m} \\
\mathrm{~m}\end{array}$ & $\begin{array}{c}12 \mathrm{~m} \\
\mathrm{~m}\end{array}$ & $\begin{array}{c}14 \mathrm{~m} \\
\mathrm{~m}\end{array}$ & $7 \mathrm{~mm}$ & $8 \mathrm{~mm}$ & $\begin{array}{c}10 \mathrm{~m} \\
\mathrm{~m}\end{array}$ & $\begin{array}{c}12 \mathrm{~m} \\
\mathrm{~m}\end{array}$ & $\begin{array}{c}14 \mathrm{~m} \\
\mathrm{~m}\end{array}$ & $\begin{array}{c}17 \mathrm{~m} \\
\mathrm{~m}\end{array}$ & $9 \mathrm{~mm}$ & $\begin{array}{c}10 \mathrm{~m} \\
\mathrm{~m}\end{array}$ & $\begin{array}{c}11 \mathrm{~m} \\
\mathrm{~m}\end{array}$ \\
\hline DMSO & $6 \mathrm{~mm}$ & $6 \mathrm{~mm}$ & $6 \mathrm{~mm}$ & $6 \mathrm{~mm}$ & $6 \mathrm{~mm}$ & $6 \mathrm{~mm}$ & $6 \mathrm{~mm}$ & $6 \mathrm{~mm}$ & $6 \mathrm{~mm}$ & $6 \mathrm{~mm}$ & $6 \mathrm{~mm}$ & $6 \mathrm{~mm}$ \\
\hline
\end{tabular}

\subsubsection{Antifungal Activity}

From the results obtained, compound $\mathbf{C}$ showed better antifungal activity even than standard fluconazole at all concentrations tested. On the other hand compound $\mathbf{A}, \mathbf{B}, \mathbf{D}$ and $\mathbf{E}$ were inactive at all concentrations tested (Table 6).

Table 7: Antifungal activities of the synthesized compounds

\section{Compound}

Zone of inhibition(mm)

CandidiaAlbicunas

Concentration $(\mu \mathrm{g} / \mathrm{ml})$

\begin{tabular}{cccc} 
& 50 & 100 & 200 \\
A & $6 \mathrm{~mm}$ & $6 \mathrm{~mm}$ & $6 \mathrm{~mm}$ \\
B & $6 \mathrm{~mm}$ & $6 \mathrm{~mm}$ & $6 \mathrm{~mm}$ \\
C & $12 \mathrm{~mm}$ & $14 \mathrm{~mm}$ & $16 \mathrm{~mm}$ \\
D & $6 \mathrm{~mm}$ & $6 \mathrm{~mm}$ & $6 \mathrm{~mm}$ \\
E & $6 \mathrm{~mm}$ & $6 \mathrm{~mm}$ & $6 \mathrm{~mm}$ \\
Fluconazole & $8 \mathrm{~mm}$ & $9 \mathrm{~mm}$ & $10 \mathrm{~mm}$ \\
DMSO & $6 \mathrm{~mm}$ & $6 \mathrm{~mm}$ & $6 \mathrm{~mm}$ \\
\hline
\end{tabular}

\subsection{Antioxidant Activity.}

Based on the experiment done on antioxidant activity from percentage inhibition, all synthesized compounds (A,

$\mathbf{B}, \mathbf{C}, \mathbf{D}, \mathbf{E})$ have shown promising antioxidant activities as compared with standard ascorbic acid starting from 29.8 to 94.4 percentage of inhibition at the tested concentrations $(12.5,25,50,100,200,400 \mu \mathrm{g} / \mathrm{ml})$ of the compounds respectively (Figure 1). Synthesized amidoalkyl naphthol A, B showed strong radical scavenging ability with an $\mathrm{IC}_{50}$ value of $24.45 \mu \mathrm{g} / \mathrm{mL}$ and $17.65 \mu \mathrm{g} / \mathrm{mL}$ respectively (Figure 2). Synthesized benzoxanthene C, D also exhibited strong radical scavenging ability with an $\mathrm{IC}_{50}$ value of $22.6 \mu \mathrm{g} / \mathrm{mL}$ and $47.56 \mu \mathrm{g} / \mathrm{ml}$ respectively where as benzoxanthene $\mathbf{E}$ showed weak antioxidant activity with an $\mathrm{IC}_{50}$ value of $60.3 \mu \mathrm{g} / \mathrm{mL}$ (Figure 2). 


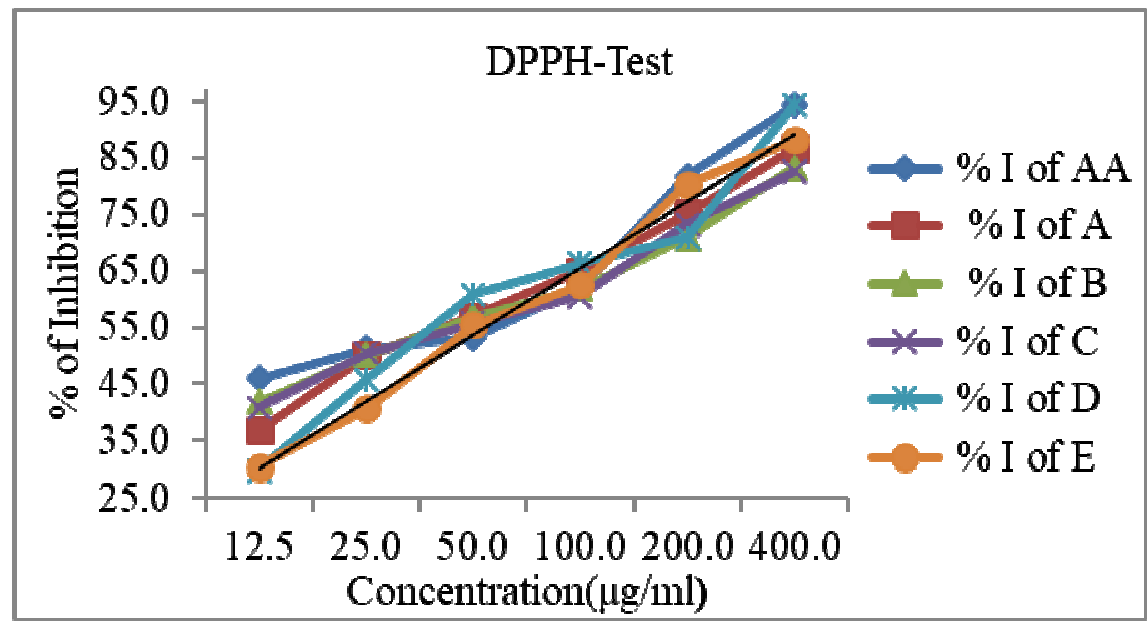

Figure 1: \% of Inhibition of synthesized compounds (A, B, C, D and E) and Ascorbic Acid

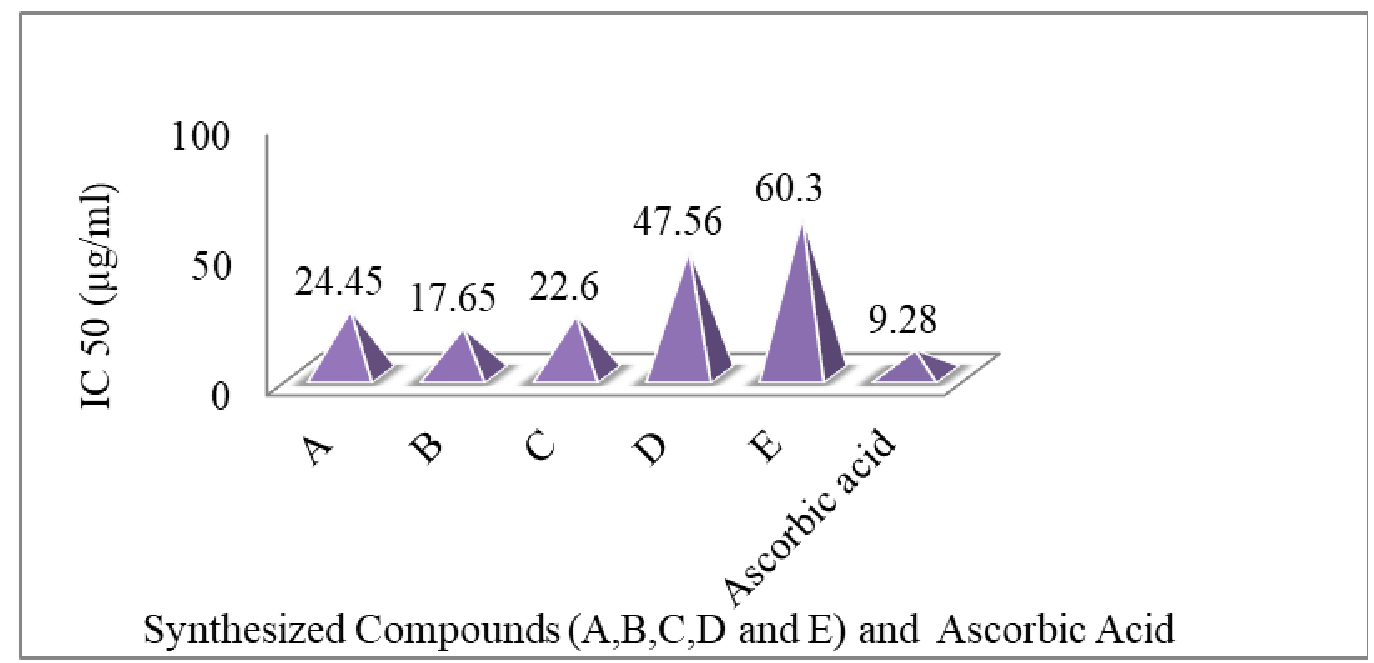

Figure 2: $\mathrm{IC}_{50}$ of synthesized compounds (A, B, C, D and E) and Standard Ascorbic Acid

\section{Conclusion and Recommendation}

From this study, zinc oxide nanoparticles ( $\mathrm{ZnO} \mathrm{NPs}$ ) was found to be an efficient, facile and environmentally green protocol to synthesis both amidoalkylnaphthols and benzoxanthenes as biologically interesting compounds. This synthetic protocol offers several advantages including inexpensive, easily available, avoidance of harmful organic solvents, high yield, short reaction time, simple work-up procedure and ease of separation compared to conventional reported methods. On the hand the biological activities results showed that benzoxanthene C, D and $\mathrm{E}$

Showed antibacterial activities against all gram negative and gram positive bacterial strains tested where as amidoalkyl naphthol A showed activity against $B$. Subtilisonly and amidoalkyl naphthol $\mathbf{B}$ was active against both $B$. subtilis and E.coli. Amongst all, the benzoxanthene $\mathbf{C}$ has only shown antifungal activity even than standard fluconazole. Except compound $\mathbf{E}$, All the remaining synthesized compounds have shown promising antioxidant activities with IC50 values of $24.45,17.65,22.6$ and $47.56 \mu \mathrm{g} / \mathrm{ml}$ for amidoalkyl naphthol A, B and benzoxanthene $\mathbf{C}$ as compared to standard ascorbic acid $(9.28 \mu \mathrm{g} / \mathrm{ml})$ respectively.

From this present research work it is recommended to synthesize additional series of amidoalkyl naphthol derivatives from benzaldehyde and its derivatives, beta-naphthol and urea or thiourea, and synthesis of benzoxanthene derivatives from benzaldehyde and its derivatives and beta-naphthol by introducing different functional groups and conduct their structure-activity relationship (SAR) analysis to explore their potency of biological activities. It is also recommended to determine potential application of the compounds to be synthesized against wide range of human pathogens.

\section{Data Availability}

The data used to support the findings of this study are available from the corresponding author upon request. 


\section{Conflict of Interest}

The authors declare that there is no conflict of interest regarding the publication of this paper.

\section{Funding}

This research work was funded by Ethiopian Institute of Agricultural Research

\section{Acknowledgement}

Authors acknowledge Ethiopian Institute of Agricultural Research (EIAR) and Adama Science and Technology University (ASTU) for the grant support to successfully carry out the project. We thank Department of Chemistry, Addis Ababa University for access to NMR, IR and UV-Vis instruments.

\section{Reference}

1. Bhushan, B., Bhagyesh, B., Suvarna, C., Kanchan, P., Pinky, B., Vikrant, S., Shailesh P., Khadabadi, S. S. (2009) Rasayan, J. Chem., 2:186.

2. Zhu, J., Bienayme, H. (2005) Multicomponent Reactions; WILEY-VCH Verlag GmbH and Company KG.

3. Kiasat, A. R., Mouradzadegun, A., Saghanezhad, S. J. (2013) Chin. J. Catal., 34: 1861.

4. Nandi, G. C., Samai, S., Kumar, R., Singh, M. S. (2009) Tetrahedron Lett., 50: 7220.

5. Dingermann, T., Steinhilber, D., Folkers, G. (2004) In Molecular Biology in Med. Chem., Wiley-VCH.

6. Shen, A. Y., Tsai, C. T., Chen, C. L. (1999) Eur. J. Med. Chem., 34: 877.

7. Safaei Ghomi, J., Zahedi, S. (2013) Monatsh. Chem., 144: 687.

8. Safaei Ghomi, J., Zahedi, S., Ghasemzadeh, M. A. (2014) Monatsh. Chem., 145:1191.

9. Peglion, J.L., Vian, J., Gourment, B., Despaux, N., Audinot, V., Millan, M. (1997) Bioorg. Med. Chem. Lett., 7:881.

10. Matsuoka, H., Ohi, N., Mihara, M., Suzuki, H., Miyamoto, K., Maruyama, N., Tsuji, K., Kato, N., Akimoto, T., Takeda, Y., Yano, K., Kuroki, T. (1997) J. Med. Chem., 40:105.

11. Limsuwan, S., Trip, E. N., Kouwen, T. R. H. M., Piersma, S., Hiranrat, A., Mahabusarakam, W., Voravuthikunchai, S. P., van Dijl, J. M., \& Kayser, O. (2009) Rhodomyrtone: A new candidate as natural antibacterial drug from Rhodomyrtus tomentosa. Phytomedicine, 16: 645-651.

12. Omolo, J. J., Johnson, M. M., van Vuuren, S. F., \& de Koning, C. B. (2011). The synthesis of xanthones, xanthenediones and spirobenzofurans: Their antibacterial and antifungal activity. Bioorganic \& Medicinal Chemistry Letters, 21: 7085-7088.

13. Hafez, H. N., Hegab, M. I., Ahmed-Farag, I. S., \& El-Gazzar, A. B. A. (2008). A facile regioselective synthesis of novel spiro-thioxanthene and spiro-xanthene-9', 2 [1, 3, 4] thiadiazole derivatives as potential analgesic and anti-inflammatory agents. Bioorganic \& Medicinal Chemistry Letters, 18: 4538-4543.

14. Banerjee, A. G., Kothapalli, L. P., Sharma, P. A., Thomas, A. B., Nanda, R. K., Shrivastava, S. K., \& Khatanglekar, V. V. (2011). A facile microwave assisted one pot synthesis of novel xanthene derivatives as potential anti-inflammatory and analgesic agents. Arabian Journal of Chemistry, in press.

15. Jamison, J. M., Krabill, K., Hatwalkar, A., Jamison, E., \& Tsai, C. C. (1990). Potentiation of the antiviral activity of polyr (A-U) by xanthene dyes. Cell Biology International Reports, 14: 1075-1084.

16. Naidu, K. R. M., Krishna, B. S., Kumar, M. A., Arulselvan, P., Khalivulla, S. I., \& Lasekan, O. (2012). Design, synthesis and antiviral potential of 14-aryl/heteroaryl-14H-dibenzo [a, j ] xanthenes using an efficient polymer-supported catalyst. Molecules, 17: 7543-7555.

17. Nishiyama, T., Sakita, K., Fuchigami, T., \& Fukui, T. (1998). Antioxidant activities of fused heterocyclic compounds, xanthene-2, 7-diols with BHT or catechol skeleton. Polymer Degradation and Stability, 62: 529-534.

18. Chatterjee, S., Iqbal, M., Kauer, J. C., Mallamo, J. P., Senadhi, S., Mallya, S., Bozyczko-Coyne, D., \& Siman, R. (1996). Xanthene derived potent nonpeptidic inhibitors of recombinant human calpain I. Bioorganic \& Medicinal Chemistry Letters, 6: 1619-1622.

19. Song, Y. B., Yang, Y. H., You, J., Liu, B., Wu, L. J., Hou, Y. L., Wang, W. J., \& Zhu, J. X. (2013). Design, synthesis and anticancer activity of N3, N11-bis (2-hydroxyethyl)-14aryl-14H-dibenzo [a, j] xanthenes-3, 11-dicarboxamide. Chemical and Pharmaceutical Bulletin, 61: 167-175.

20. Bhattacharya, A. K., Rana, K. C., Mujahid, M., Sehar, I., \& Saxena, A. K. (2009). Synthesis and in vitro study of 14- aryl-14H-dibenzo [a, j] xanthenes as cytotoxic agents. Bioorganic \& Medicinal Chemistry Letters, 19: 5590-5593.

21. Kumar, A., Sharma, S., Maurya, R. A., \& Sarkar, J. (2010). Diversity oriented synthesis of benzoxanthene and benzochromene libraries via one-pot, three-component reactions and their anti-proliferative activity. Journal of Combinatorial Chemistry, 12: 20-24.

22. K.H. Kumar, P.T.Perumal, (2007), Tetrahedron, 63(38), 9531-9535.

23. Melagraki, Afantitis et al. (2006), Bioorga. Med. Chem., 14: pp. 1108-1114. 
24. Seema, R., Poonam, S., Shishodia, P.K., Mehra, R.M. (2008), 92: 1639-1645.

25. Kantevari,S., Vuppalapati S V , Nagarapu, L. (2007) Catal. Commun., 8:1857-1862.

26. Nagarapu, L., Baseeruddin, M., Apuri, S., Kantevari, S. (2007) Catal. Commun.,8: 1729-1734.

27. Selvam,N.P., Perumal,P.T. (2006) A new synthesis of acetamido phenols promoted by Ce $\left(\mathrm{SO}_{4}\right)_{2}$, Tetrahedron Lett., 47 :7481-7483.

28. Kshama, K., NAYAK, S. K. (2014) J. Serb. Chem. Soc., 79 (9): 1051-1058.

29. Hashemi, H., Sardarian, A. R. (2013) IJST.,A1: 75-82.

30. Masoud, N. E, Tooba, A. (2013) Rev. Roum. Chim.,58(1): 27-35.

31. Singh R. K., Bale R., Duvedi R, Kumer S. (2015) Iranian J. Catalyst, 5:187.

32. Amrollali M A., Mirjalili B B F., Emtiazi H.(2013) J. Chem. Sci.,125:561.

33. Said S., Mashaly M., Sheta A., Emorsy S.(2015)Int. J. Org. Chem.,5:191. 